\title{
Bi-substituted $\mathrm{Mg}_{3} \mathrm{Al}-\mathrm{CO}_{3}$ layered double hydroxides
}

\author{
Denis Sokol $^{1} \cdot$ Andrei N. Salak $^{2} \cdot$ Mário G. S. Ferreira $^{2} \cdot$ Aldona Beganskiene $^{1} \cdot$ \\ Aivaras Kareiva ${ }^{1}$
}

\begin{abstract}
Magnesium-aluminium-bismuth-layered double hydroxides (LDH) intercalated with carbonate were studied in respect of maximal rate of substitution of $\mathrm{Al}^{3+}$ by $\mathrm{Bi}^{3+}$ for the first time. $\mathrm{LDH}$ with the nominal compositions of $\mathrm{Mg}_{3} \mathrm{Al}_{1-x} \mathrm{Bi}_{x}-\mathrm{CO}_{3}$ ( $x=0$ to 0.5 ) were prepared using both the conventional super saturation co-precipitation method and sol-gel processing via hydration of the mixed oxide powders in carbonate-containing solutions. The mixed oxides were obtained either by calcination of the LDH (prepared by co-precipitation) or by using a novel alkoxide-free sol-gel method. All the LDH products were characterised using the methods of X-ray diffraction, scanning electron microscopy and thermogravimetry. The observed values of the lattice parameters of LDH phases were compared with the calculated values. It has been found that, regardless of the preparation method used and the conditions ( $\mathrm{pH}$, temperature, time) applied, the maximum rate of substitution of aluminium by bismuth in LDH is about $20 \mathrm{~mol} . \%$.
\end{abstract}

Graphical abstract A schematic representation of LDH structure of a $3 \mathrm{R}$ polytype $[4,5]$ where the lattice parameter

Denis Sokol

denis.sokol@chf.vu.lt

1 Department of Inorganic Chemistry, Vilnius University, Naugarduko 24, LT-03225 Vilnius, Lithuania

2 Department of Materials and Ceramic Engineering and CICECO Aveiro Institute of Materials, University of Aveiro, 3810-193 Aveiro, Portugal $c$ and the basal spacing $d$ relate to each other as $c=3 d$.

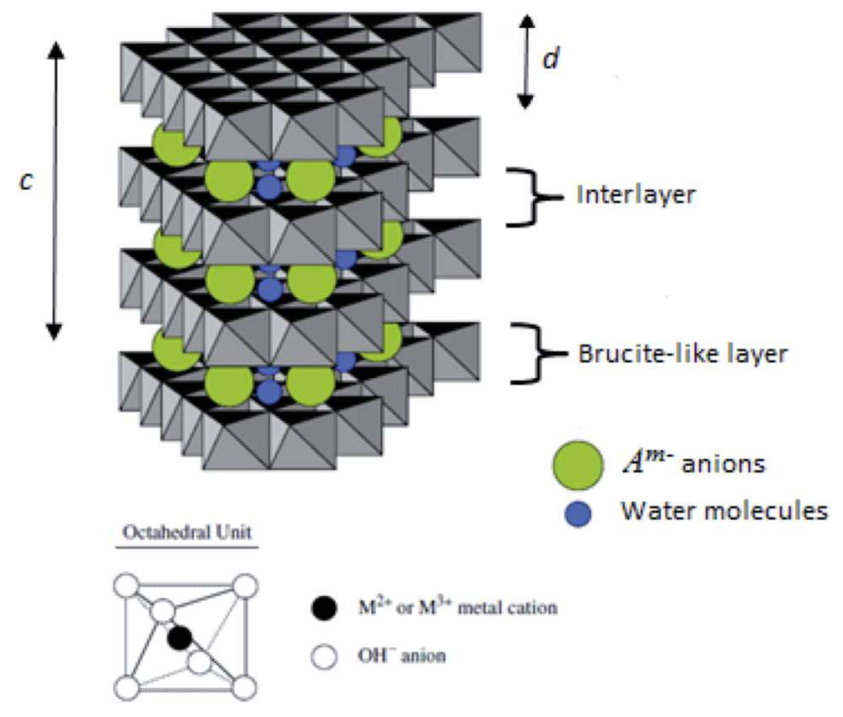

Keywords Layered double hydroxide • Cation substitution • Bismuth - Co-precipitation, Alkoxide-free sol-gel method

\section{Introduction}

Layered double hydroxides (LDH), also known as hydrotalcite-type compounds, belong to a family of anionic clays whose crystal structure is derived from brucite, $\mathrm{Mg}$ $(\mathrm{OH})_{2}$. In LDH, the positively charged layers of double metal hydroxides alternate with charge-compensating interlayer of anions coordinated by water molecules [1]. Although $M^{\mathrm{I}}-M^{\mathrm{III}}$ LDH are known [2, 3], the great majority of layered hydroxides are of the $M^{\mathrm{II}}-M^{\mathrm{III}}$ type. 
The general chemical formula of such LDH can be represented as $\left.\left[M^{\mathrm{II}}{ }_{1-{ }_{n}} M^{\mathrm{III}}{ }_{n}(\mathrm{OH})_{2}\right]^{n+}\left(A^{m-}\right)_{n / m}\right] \cdot z \mathrm{H}_{2} \mathrm{O}$.

The metal cations in the hydroxide layers are coordinated by six oxygen atoms forming 2-D structures of the facelinked oxygen octahedra (Fig. 1). The octahedra are compressed in the direction perpendicular to the layer planes [1].

LDH compositions are typically characterised by hexagonal symmetry with the $c$-axis perpendicular to the layers. The characteristic scale of the layer-interlayer structure (basal plane spacing, $d$ ) in LDH can be between about 0.75 $\mathrm{nm}$ to several nanometres depending on the composition and arrangement of species in the interlayer. The hydroxide layers can be stacked in different ways that results in different $\mathrm{LDH}$ polytypes $[4,5]$. Therefore, the $c$-parameter is a multiple of $d$ with a factor of either 3 or 2 depending on the polytype (Fig. 1). The basal spacing value depends on size, charge and orientation of the intercalated anions as well as the relative amount of crystal water. Parameter $a$ is a function of both the $M^{\mathrm{II}}$ and $M^{\mathrm{III}}$ cations size and ratio, and is typically within $0.30-0.31 \mathrm{~nm}$.

The lattice parameters $a$ and $c$ can be independently calculated from the angle positions of the (110) diffraction reflection and the $(00 l)$ reflections family, respectively. When LDH are intercalated with single-atom anions or with some other simple anions that are arranged parallel to the hydroxide layers, the crystal symmetry is known (e.g., $R 3 m$ for $\mathrm{Zn}-\mathrm{Al}$ and $\mathrm{Mg}-\mathrm{Al} \mathrm{LDH}$ intercalated with $\mathrm{Cl}^{-}$[6], $\mathrm{OH}^{-}$ [7], $\mathrm{CO}_{2}{ }^{2-}$ [8]. However, in the cases of large polyatomic anions [9], the real symmetry of the crystal lattice can be lower than rhombohedral or still rhombohedral but with a higher value of $a$-parameter. This results in appearance of

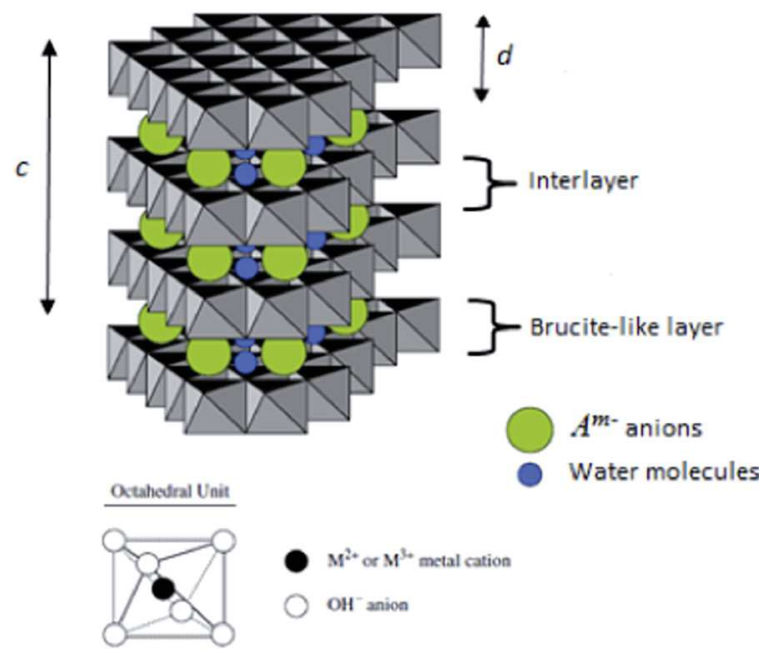

Fig. 1 A schematic representation of LDH structure of a 3R polytype where the lattice parameter $c$ and the basal spacing $d$ relate to each other as $c=3 d[4,5]$ additional peaks in the X-ray powder diffraction (XRD) pattern that complicates identification of LDH phase.

Numbers of pairs of $M^{\mathrm{II}}-M^{\mathrm{III}}$ cations were experimentally used to estimate the ranges of the relative sizes of the cations that can form an LDH structure. In a majority of the known $M^{\mathrm{II}}-M^{\mathrm{III}} \mathrm{LDH}, M^{\mathrm{II}}$ is cation of magnesium or a 4 thperiod transition metal from iron to zinc, and $M^{\mathrm{III}}$ is, as a rule, $\mathrm{Al}, \mathrm{Ga}, \mathrm{Fe}$, or $\mathrm{Cr}$ [3]. In such combinations, the divalent metal cation is slightly bigger than the trivalent one. At the same time, the LDH compounds containing the relatively large $M^{\mathrm{II}}$ cations, namely Ca [10, 11] and Cd [12] were successfully prepared and thoroughly characterised. $\mathrm{LDH}$ that contain either $\mathrm{Ba}$ as a divalent cation [13] or Ce as a trivalent cation [14] were reported as well. However, no convincing proof that those LDH were formed indeed has been afforded in these publications. Besides, some authors declared preparation of $M^{\mathrm{II}}-M^{\mathrm{III}} \mathrm{LDH}$, where $M^{\mathrm{III}}$ is $\mathrm{Bi}$ $[15,16]$ but the respective XRD patterns were either not presented or very doubtful.

It should be pointed out that Bi-containing $\mathrm{LDH}$ are potentially of great interest. $\mathrm{Bi}^{\mathrm{III}}$ has a stereochemically active lone pair of electrons. This feature of bismuth is associated with onset of unusual dielectric relaxation in oxygen octahedral phases that contain $\mathrm{Bi}^{\mathrm{III}}$ coordinated by $12(8+4)$ oxygens [17, 18]. Besides, polar (antipolar) ordering in oxygen octahedral multiferroics is typically resulted from parallel (antiparallel) displacements of $\mathrm{Bi}^{\mathrm{III}}$ $[19,20]$. Although trivalent bismuth is a relatively large cation, there are compounds with $\mathrm{Bi}^{\mathrm{III}}$ coordinated by six oxygens $[21,22]$. In those compounds, the $\mathrm{BiO}_{6}$ octahedra are corner-linked; moreover, they are surrounded by octahedra with smaller-size cations. Such alternation of the octahedra allows to accommodate $\mathrm{Bi}^{\mathrm{III}}$ in the structure.

In LDH structure, the octahedra $M^{\mathrm{II}} \mathrm{O}_{6}$ and $M^{\mathrm{III}} \mathrm{O}_{6}$ in hydroxide layer are face-linked (Fig. 1). One can expect that LDH that contain relatively small divalent cations and relatively large trivalent cations can be stable at the cation ratio of $M^{\mathrm{II}} / M^{\mathrm{III}}=3: 1$ with the ordered arrangement, when every $M^{\mathrm{III}} \mathrm{O}_{6}$ octahedron is coordinated by the $M^{\mathrm{II}} \mathrm{O}_{6}$ octahedra only [1]. Phenomenon of the cation ordering in $\mathrm{LDH}$ is rare and little investigated [1]. Taking into account a likely deformation of the $\mathrm{BiO}_{6}$ octahedra in the hydroxide layers and the cation displacements, $\mathrm{a} \mathrm{Bi}^{\mathrm{III}}$-containing $\mathrm{LDH}$ compound could appear to be an example of a 2-D multiferroic material that combines elastic and polar order parameters.

This work was aimed at investigation of feasibility of preparation of $\mathrm{LDH}$ compounds with $M^{\mathrm{III}}=\mathrm{Bi}$. We report on a study of formation of compositions derived from a carbonate-intercalated $\mathrm{Mg}-\mathrm{Al} \mathrm{LDH}$ by means of a gradual substitution of aluminium by bismuth. $\mathrm{Mg}_{3} \mathrm{Al}-\mathrm{CO}_{3}$ was chosen as a parent composition since this LDH is one of the most-studied. Besides, it was found from theoretical 
calculations that $\mathrm{Mg}_{1-n} \mathrm{Al}_{n} \mathrm{LDH}$ are most stable for $n=$ 0.25 (i.e., when $\mathrm{Mg} / \mathrm{Al}=3: 1$ ) [23]. In order to minimise a possible effect of processing on the chemical composition of the resulting product, two independent methods were used to prepare $\mathrm{LDH}$ with the $\mathrm{Mg}_{3} \mathrm{Al}_{1-x} \mathrm{Bi}_{x}$ cation content $(x=0$ to 0.5$)$, namely the conventional co-precipitation method and a formation via hydration of the mixed oxide powders in the carbonate-containing solutions. The powders were obtained either by calcination of the LDH (prepared by co-precipitation) or by using a novel alkoxide-free sol-gel method.

\section{Experimental}

\subsection{Materials}

For the synthesis of $\mathrm{LDH}$ these materials have been used: $\mathrm{Al}\left(\mathrm{NO}_{3}\right)_{3} .9 \mathrm{H}_{2} \mathrm{O}$ (98\%, POCH S.A.), $\mathrm{Mg}\left(\mathrm{NO}_{3}\right)_{2} \cdot 6 \mathrm{H}_{2} \mathrm{O}$ (99\%, Fluka); $\mathrm{Bi}\left(\mathrm{NO}_{3}\right)_{3} .5 \mathrm{H}_{2} \mathrm{O}\left(98 \%\right.$, Fluka), $\mathrm{HNO}_{3}(66 \%$, REACHEM s.r.o.), ethylene glycol $\mathrm{C}_{2} \mathrm{H}_{6} \mathrm{O}_{2}(99 \%$, SigmaAldrich), $\mathrm{CH}_{3} \mathrm{COOH}$ (99\%, REACHEM s.r.o.). Deionised water was used in all syntheses, preparation of solutions and washing of final compounds.

\subsection{Synthesis of $\mathrm{Mg}_{3} \mathrm{Al}_{1}{ }_{x} \mathrm{Bi}_{x} \mathrm{LDH}$ via co-precipitation method}

$\mathrm{Mg}_{3} \mathrm{Al}_{1} \mathrm{LDH}$ was prepared by the co-precipitation under low super saturation out of a solution of the appropriate metal nitrates $\mathrm{Al}\left(\mathrm{NO}_{3}\right)_{3} \cdot 9 \mathrm{H}_{2} \mathrm{O}$ and $\mathrm{Mg}\left(\mathrm{NO}_{3}\right)_{2} \cdot 6 \mathrm{H}_{2} \mathrm{O}$ with a molar ratio of $\mathrm{Mg}: \mathrm{Al}=3: 1$ and a solution of $\mathrm{NaHCO}_{3}$ : $\mathrm{NaOH}$ with a molar ratio of 1:2. The solution of metal nitrates was slowly poured into the solution of $\mathrm{NaHCO}_{3}+$ $\mathrm{NaOH}(\mathrm{pH} \approx 12)$ under vigorous stirring. After mixing, the obtained slurry was aged at a temperature of $80^{\circ} \mathrm{C}$ for $6 \mathrm{~h}$. The slurry was filtered and washed with distilled water and dried in an oven at a temperature of $60{ }^{\circ} \mathrm{C}$. The resulting powders were labelled as $\mathrm{Mg}_{3} \mathrm{Al}_{1 \text { (co-pr) }}$. The mixed-metal oxide obtained by subsequent heating at a temperature of $650{ }^{\circ} \mathrm{C}$ for $3 \mathrm{~h}$ was labelled as $\mathrm{Mg}_{3} \mathrm{Al}_{1 \text { (co-pr/cal). The }}$ hydration was carried out in water at a temperature of $80^{\circ} \mathrm{C}$ for $6 \mathrm{~h}$ at $\mathrm{pH} \approx 8.5$. The $\mathrm{LDH}$ sample restored in water was

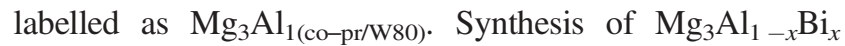
compounds was carried out in the same way as $\mathrm{Mg}_{3} \mathrm{Al}_{1} \mathrm{LDH}$ except $\mathrm{Bi}\left(\mathrm{NO}_{3}\right)_{3} .5 \mathrm{H}_{2} \mathrm{O}$ was dissolved in $1 \mathrm{M} \mathrm{HNO}_{3}$, since

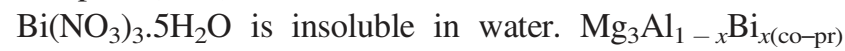
compounds were prepared using cation molar ratio from $x$ $=0.1$ to $x=0.5$.The mixed-metal oxides obtained by sub-

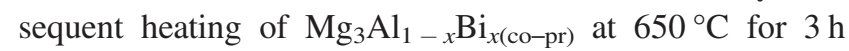
were labelled as $\mathrm{Mg}_{3} \mathrm{Al}_{1-x} \mathrm{Bi}_{x(\mathrm{co}-\mathrm{pr} / \mathrm{cal})},(x=0.1$ to $x=0.5)$. The hydration was carried out also in water at $80^{\circ} \mathrm{C}$ for $6 \mathrm{~h}$ at $\mathrm{pH} \approx 8.5$. The samples restored in water were labelled as

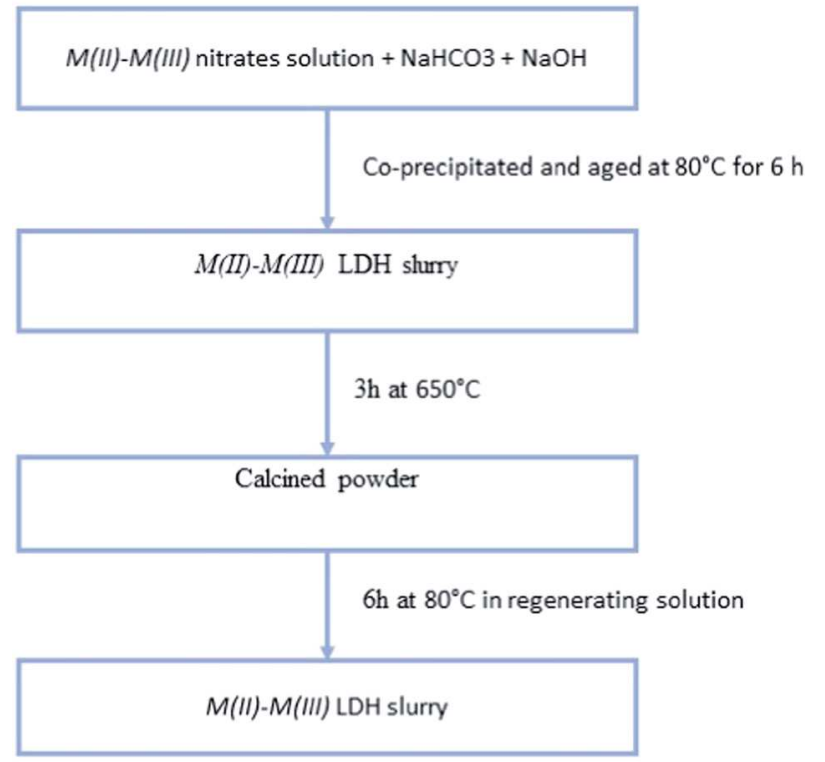

Fig. 2 Schematic representation of the LDH preparation by coprecipitation method

$\mathrm{Mg}_{3} \mathrm{Al}_{1-{ }_{x}} \mathrm{Bi}_{x(\mathrm{co}-\mathrm{pr} / \mathrm{W} 80)}$. After the restoration processes, the samples were washed with water and dried in air. A schematic representation of the preparation of $\mathrm{LDH}$ by coprecipitation method is shown in Fig. 2.

\subsection{Synthesis of $\mathrm{Mg}_{3} \mathrm{Al}_{1}-{ }_{x} \mathrm{Bi}_{x} \mathrm{LDH}$ via sol-gel method}

$\mathrm{Mg}_{3} \mathrm{Al}_{1} \mathrm{LDH}$ was prepared by mixing the solutions of the appropriate metal nitrates with a molar ratio of $\mathrm{Mg}: \mathrm{Al}=$ 3:1. The nitrates were dissolved in $50 \mathrm{ml}$ of distilled water with addition of $50 \mathrm{ml}$ of $0.2 \mathrm{M}$ acetic acid. Then, the solution has been stirred for $1 \mathrm{~h}$ at $80{ }^{\circ} \mathrm{C}$. Next, $2 \mathrm{ml}$ of ethylene glycol was added under continuous stirring for $4 \mathrm{~h}$ at the same temperature. After slow evaporation of solvent, the obtained gel was dried at $120-140{ }^{\circ} \mathrm{C}$ for $10-14 \mathrm{~h}$ (obtained compound was labelled as $\mathrm{Mg}_{3} \mathrm{Al}_{1(\mathrm{sg})}$ ). The mixed-metal oxide obtained by subsequent heating of the precursor gel at $650{ }^{\circ} \mathrm{C}$ for $3 \mathrm{~h}$ was labelled as $\mathrm{Mg}_{3}$ $\mathrm{Al}_{1(\mathrm{sg} / \mathrm{cal})}$. The hydration of $\mathrm{Mg}_{3} \mathrm{Al}_{1 \text { (sg/cal) }}$ was carried out in water at $80^{\circ} \mathrm{C}$ for $6 \mathrm{~h}$ at $\mathrm{pH} \approx 8.5$. The sample restored in

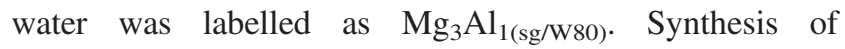
$\mathrm{Mg}_{3} \mathrm{Al}_{1-x} \mathrm{Bi}_{x}$ compounds was carried out in the same way as $\mathrm{Mg}_{3} \mathrm{Al}_{1}$ except $\mathrm{Bi}\left(\mathrm{NO}_{3}\right)_{3} \cdot 5 \mathrm{H}_{2} \mathrm{O}$ was dissolved in $1 \mathrm{M}$ $\mathrm{HNO}_{3} \cdot \mathrm{Mg}_{3} \mathrm{Al}_{1-x} \mathrm{Bi}_{x(\mathrm{sg})}$ compounds were synthetised using cation molar ratio from $x=0.1$ to $x=0.5$.The mixed-metal oxides were obtained by subsequent heating of $\mathrm{Mg}_{3}$

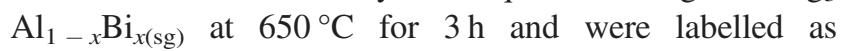
$\mathrm{Mg}_{3} \mathrm{Al}_{1-x} \mathrm{Bi}_{x(\mathrm{sg} / \mathrm{cal})}$. The hydration was carried out in water at $80{ }^{\circ} \mathrm{C}$ for $6 \mathrm{~h}$ at $\mathrm{pH} \approx 8.5$. The samples restored in water were labelled as $\mathrm{Mg}_{3} \mathrm{Al}_{1-x} \mathrm{Bi}_{x(\mathrm{sg} / \mathrm{W} 80)}$. After the restoration processes, the samples were washed with water and dried 


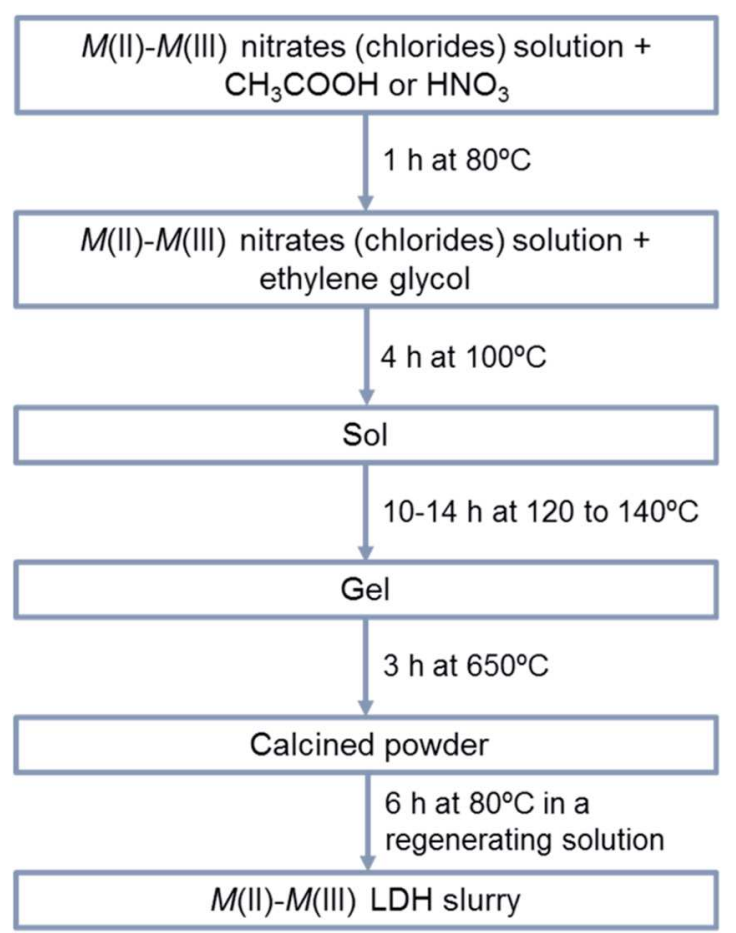

Fig. 3 Schematic representation of the non-conventional LDH preparation by sol-gel method

in air. A schematic representation of the preparation of $\mathrm{LDH}$ by sol-gel method is shown in Fig. 3.

\subsection{Characterisation techniques}

The XRD patterns of the samples were recorded with a conventional Bragg-Brentano geometry $(\theta-2 \theta$ scans $)$ on Rigaku MiniFlexII diffractometer using $\mathrm{Cu} \mathrm{K}_{\alpha}$ radiation $(\lambda$ $=1.541838 \AA$ ). The patterns were recorded from 8 to $80^{\circ}$ $2 \theta$ angle at a step size of $0.02^{\circ}$ and at speed time $5^{\circ} / \mathrm{min}$. Morphology of synthesised compounds were investigated by scanning electron microscopy (SEM) using scanning electron microscope Hitachi SU-70. Thermogravimetric (TG) analysis was carried out using PerkinElmer STA6000 apparatus. Measurements were collected by heating the samples from 30 to $995^{\circ} \mathrm{C}$ degrees at heating rate of $10 \mathrm{~K}$ /min.

\section{Results and discussion}

The powder XRD patterns of LDH synthesised by coprecipitation and sol-gel methods are shown in Figs. 4, 5, respectively. The XRD pattern of $\mathrm{Mg}_{3} \mathrm{Al}_{1} \mathrm{LDH}$ made by co-precipitation method (Fig. 4) is typical XRD pattern for the LDH showing the common features of layered materials, such as narrow, symmetric, strong lines at low $2 \theta$ values and weaker, less symmetric lines at high $2 \theta$ values.

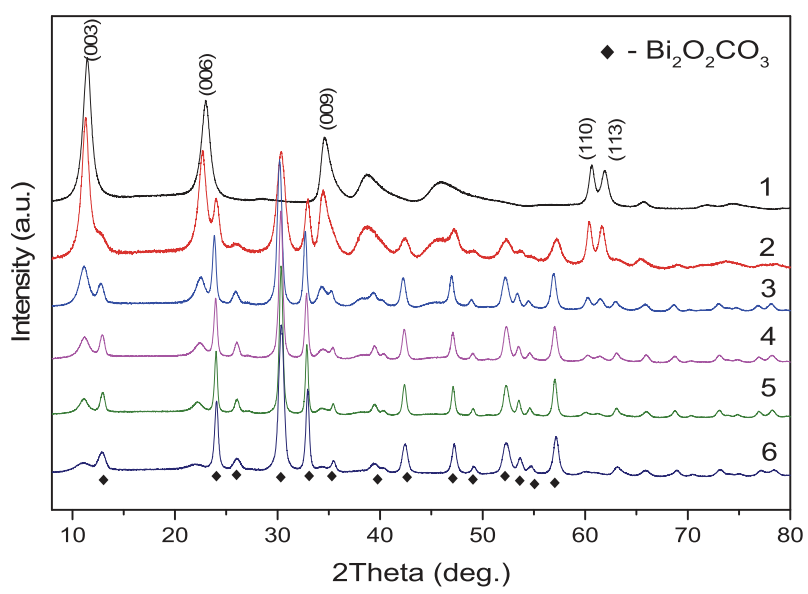

Fig. 4 XRD patterns of the LDH synthesis products obtained by co-precipitation method with the nominal $\mathrm{Mg}_{3} \mathrm{Al}_{1-x} \mathrm{Bi}_{x}$ cation composition: $x=0$ (1), $x=0.1$ (2), $x=0.2$ (3), $x=0.3$ (4), $x=0.4$ (5) and $x=0.5$ (6). The characteristic diffraction reflections of the LDH phase are indexed

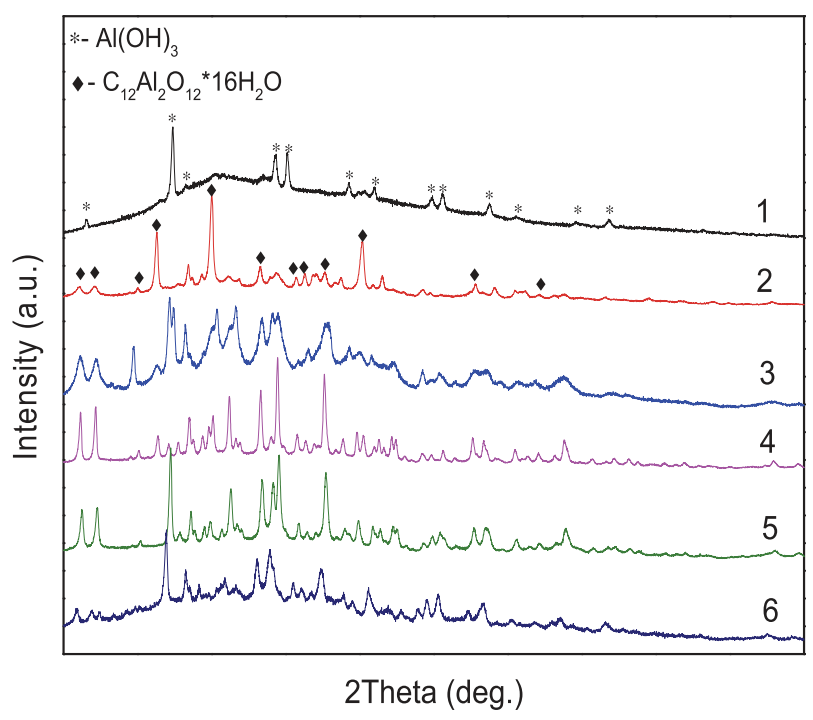

Fig. 5 XRD patterns of the LDH synthesis products obtained by sol-gel method with the nominal $\mathrm{Mg}_{3} \mathrm{Al}_{1-x} \mathrm{Bi}_{x}$ cation composition: $x=0 \quad$ (1), $x=0.1$ (2), $x=0.2$ (3), $x=0.3$ (4), $x=0.4$ (5) and $x=0.5(6)$

However, the LDH obtained by sol-gel method (Fig. 5) contains many organic impurities and shows very low crystallinity. Majority of the peaks are wide or being smudged and it is not possible to identify typical LDH peaks, all other peaks which can be identified are assigned to $\mathrm{Al}(\mathrm{OH})_{3}$ (JCPDS 76-1782) and $\mathrm{C}_{12} \mathrm{Al}_{2} \mathrm{O}_{12} *{ }_{16} \mathrm{H}_{2} \mathrm{O}$ (JCPDS 42-1501). These results confirm that alkoxide-free sol-gel method is not suitable for the direct synthesis of LDH.

The powder XRD patterns of bismuth-substituted $\mathrm{Mg} / \mathrm{Al} /$ Bi LDH samples (Bi substitution level was from 0 to $50 \%$ ) 
fabricated by the same methods are also shown in Figs. 4, 5. In the case of co-precipitation synthesis of Bi-substituted $\mathrm{Mg}_{3} \mathrm{Al}_{1-x} \mathrm{Bi}_{x}$ compounds, the diffraction lines of side phase $\mathrm{Bi}_{2} \mathrm{O}_{2} \mathrm{CO}_{3}$ (JCPDS 41-1488) along with $\mathrm{Mg} / \mathrm{Al} / \mathrm{Bi}$ LDH peaks are seen in the XRD patterns (Fig. 4). With increasing substitutional level of bismuth, the intensities of the reflections of $\mathrm{Bi}_{2} \mathrm{O}_{2} \mathrm{CO}_{3}$ phase also monotonically increased and the peaks of $\mathrm{Mg} / \mathrm{Al} / \mathrm{Bi}$ phase became less intensive. Thus, the formation of layered structure becomes problematic when the amount of bismuth exceeds $>20 \%$. On the other hand, $\mathrm{Mg} / \mathrm{Al} / \mathrm{Bi} \mathrm{LDH}$ was not formed during the sol-gel processing.

All LDH undergo thermal decomposition at high temperatures. Therefore, thermal stabilities of the materials were investigated by TG analysis. Different synthesis method gives different thermal behaviour. TG curves of $\mathrm{Mg}_{3} \mathrm{Al}_{0.5} \mathrm{Bi}_{0.5} \mathrm{LDH}$ and sol-gel precursor are shown in Figs. 6, 7, respectively. As seen from Fig. 6, the first mass loss observed from room temperature up to $200{ }^{\circ} \mathrm{C}$ is due to the removal of interlayer and absorbed water [24]. The decomposition of interlayer hydroxyl and carbonate anions occurs in the temperature range of $300-600^{\circ} \mathrm{C}$. The presence of a single and monotonical mass loss in this range confirms that dehydroxylation and decarbonation processes occur simultaneously. No mass loss was observed above

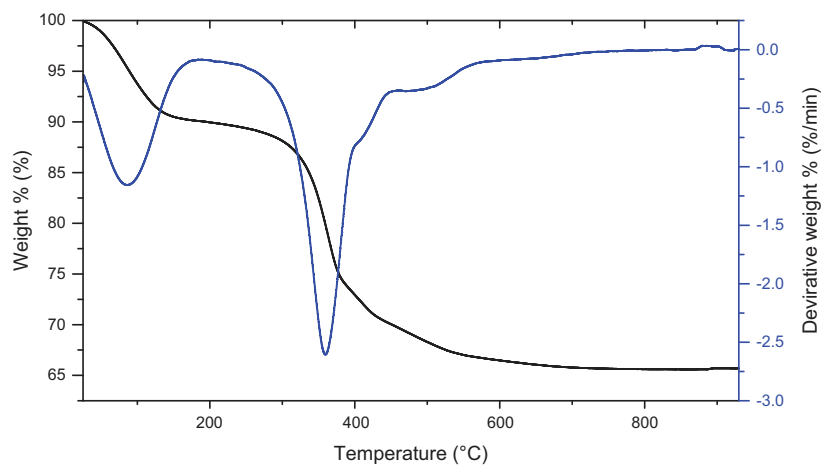

Fig. 6 TG-DTG curves of $\mathrm{Mg}_{3} \mathrm{Al}_{0.5} \mathrm{Bi}_{0.5(\mathrm{co}-\mathrm{pr})}$ sample prepared by co-precipitation method

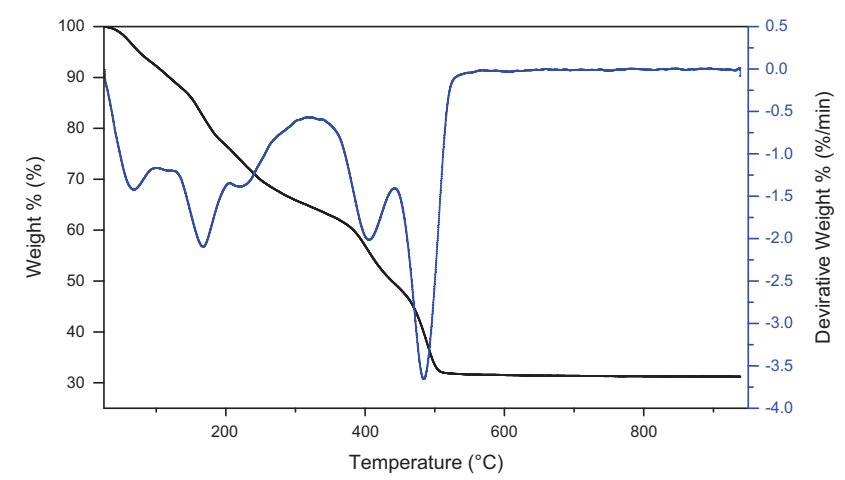

Fig. 7 TG-DTG curves of $\mathrm{Mg}_{3} \mathrm{Al}_{0.5} \mathrm{Bi}_{0.5(\mathrm{sg})}$ sol-gel precursor this temperature. In Fig. 7, thermal decomposition of sol-gel-derived precursor $\mathrm{Mg}_{3} \mathrm{Al}_{0.5} \mathrm{Bi}_{0.5(\mathrm{sg})}$ occurs in three steps. In the first step, the differential thermogravimetry (DTG) curve shows two minima at 50 and $170{ }^{\circ} \mathrm{C}$. This mass loss could be associated with the dehydration process. The second step is observed in the temperature range of $200-400{ }^{\circ} \mathrm{C}$ and is related with thermal decomposition of the organic part of gel. The last mass loss is observed between 400 and $500{ }^{\circ} \mathrm{C}$. This may be associated with decomposition of ionic carbonate and burning of residual organics.

The annealing temperature of $\mathrm{LDH}$ is very important because it is crucial for the successful reconstitution of the layered structure. The heat treatment of LDH should be performed at higher temperature than the temperature used for the destruction of double layers, but at lower temperature than the temperature suitable for the formation of spinel or another insoluble phase. Thus, for $\mathrm{LDH}$ the calcination temperature is usually set between 400 and $700{ }^{\circ} \mathrm{C}$ [1]. The TG results in Figs. 6, 7 show that the decomposition temperature of $\mathrm{Mg}_{3} \mathrm{Al}_{0.5} \mathrm{Bi}_{0.5(\mathrm{co}-\mathrm{pr})}$ and $\mathrm{Mg}_{3} \mathrm{Al}_{0.5} \mathrm{Bi}_{0.5(\mathrm{sg})}$ samples should be around 600 and $500{ }^{\circ} \mathrm{C}$, respectively. Consequently, the $\mathrm{Mg}_{3} \mathrm{Al}_{1-{ }_{x}} \mathrm{Bi}_{x} \mathrm{LDH}$ prepared by coprecipitation method and the same sol-gel precursors were annealed in a slightly wider temperature range of 450-850 C. The XRD patterns of obtained synthesis products are presented in Figs. 8, 9. The XRD patterns show that in both synthesis the spinel $\mathrm{MgAl}_{2} \mathrm{O}_{4}$ (JCPDS 21-1152) phase is forming at temperature higher than $700{ }^{\circ} \mathrm{C}$. These spinel containing solids cannot be converted back to the layered structure. $\mathrm{Bi}_{2} \mathrm{O}_{3}$ (JCPDS 50-1088) phase, which is also very low soluble in water, is forming at lower annealing temperatures $\left(450{ }^{\circ} \mathrm{C}\right.$ co-precipitation method and $550{ }^{\circ} \mathrm{C}$ sol-gel method). The XRD patterns of synthesis products

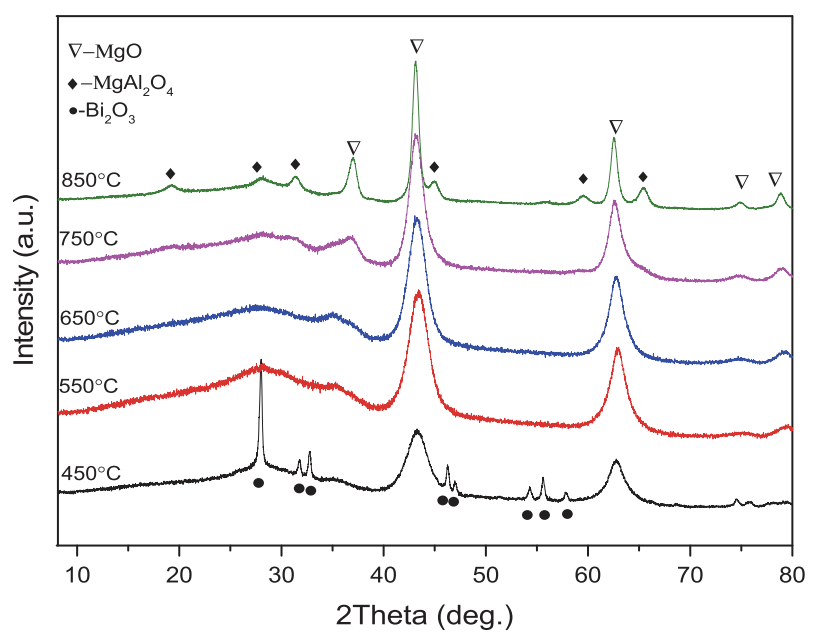

Fig. 8 XRD patterns of the synthesis products obtained by annealing $\mathrm{Mg}_{3} \mathrm{Al}_{0.9} \mathrm{Bi}_{0.1} \mathrm{LDH}$ prepared via co-precipitation method at different temperatures 


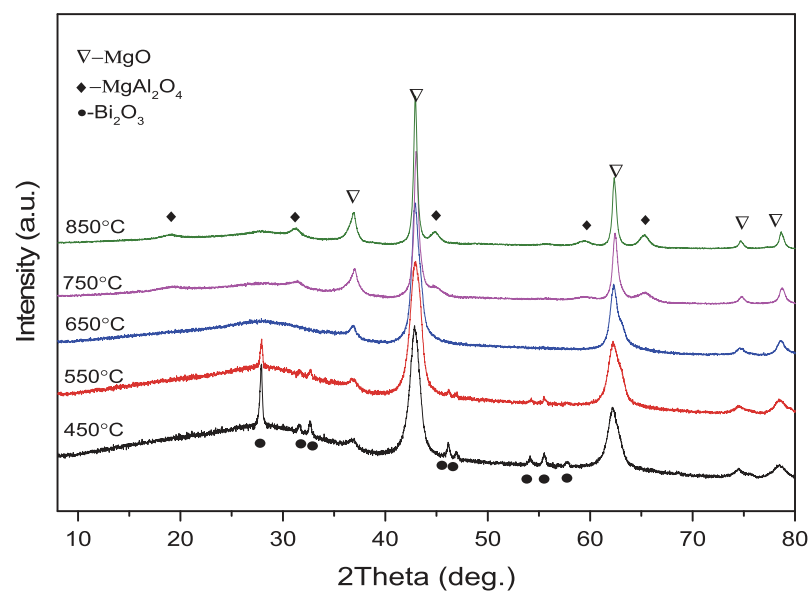

Fig. 9 XRD patterns of the synthesis products obtained by annealing $\mathrm{Mg}_{3} \mathrm{Al}_{0.9} \mathrm{Bi}_{0.1}$ sol-gel precursor at different temperatures

obtained at $650{ }^{\circ} \mathrm{C}$ revealed that in both cases poorly crystalline magnesium oxide $\mathrm{Mg}(\mathrm{Al}) \mathrm{O}$ or $\mathrm{Mg}(\mathrm{AlBi}) \mathrm{O}$ (reflections at $2 \theta$ angles $\approx 36,43,63,75$ and 79) was formed. Therefore, the same temperature of $650{ }^{\circ} \mathrm{C}$ has been selected for the thermal treatment of all Bi-substituted samples.

In Figs. 10, 11, the XRD patterns of $\mathrm{Mg}_{3} \mathrm{Al}_{1-x} \mathrm{Bi}_{x(\mathrm{co}-\mathrm{pr})}$ and $\mathrm{Mg}_{3} \mathrm{Al}_{1-x} \mathrm{Bi}_{x(\mathrm{sg})}$ samples annealed at $650{ }^{\circ} \mathrm{C}$ are shown, respectively. As seen from XRD patterns, the $\mathrm{Mg}_{3} \mathrm{Al}_{1-x} \mathrm{Bi}_{x \text { (co-pr) }} \mathrm{LDH}$ could be easily converted to mixed metal oxides (MMO) by a simple heat-treatment at $650{ }^{\circ} \mathrm{C}$. However, at higher concentrations of bismuth (40-50\%) the XRD patterns contain not only reflections of $\mathrm{MgO}$ (JCPDS 45-0946) phase, but also extra peaks of $\mathrm{Bi}_{48} \mathrm{Al}_{2} \mathrm{O}_{75}$ (JCPDS 42-0199) and $\mathrm{Bi}_{2} \mathrm{O}_{3}$ phases. As was discussed previously, those phases are insoluble in water; therefore, full reconstruction of $\mathrm{LDH}$ from these samples would be not possible. The XRD patterns of heat-treated at the same temperature $\mathrm{Mg}_{3} \mathrm{Al}_{1-x} \mathrm{Bi}_{x(\mathrm{sg})}$ precursor gels are given in Fig. 11. Interestingly, with increasing amount of $\mathrm{Bi}$ all reflections are slightly moved to higher $2 \theta$ angles. This is a consequence of incorporation of aluminium and bismuth in the framework of $\mathrm{Mg}(\mathrm{Al}) \mathrm{O}$ or $\mathrm{Mg}(\mathrm{AlBi}) \mathrm{O}$, resulting in the formation of mixed-metal oxides [1]. In both cases, when amount of bismuth did not exceed 10-30\%, only low crystallinity single-phase mixed-metal oxides were obtained, and no peaks assigned to the $\mathrm{MgAl}_{2} \mathrm{O}_{4}, \mathrm{Bi}_{2} \mathrm{O}_{3}$ or $\mathrm{Bi}_{48} \mathrm{Al}_{2} \mathrm{O}_{75}$ phases were observed. Consequently, these results clearly show the possibility to reform MMO containing bismuth to the $\mathrm{LDH}$.

The reformation process of LDH in water back to layered structurefrom mixed-metal oxides ("memory effect") was also investigated in this study. The XRD patterns of LDH samples obtained after reconstruction process at $80{ }^{\circ} \mathrm{C}$ in water solution are given in Figs. 12, 13. MMO obtained from pure $\mathrm{Mg} / \mathrm{Al} \mathrm{LDH}$ and synthetised by sol-gel method

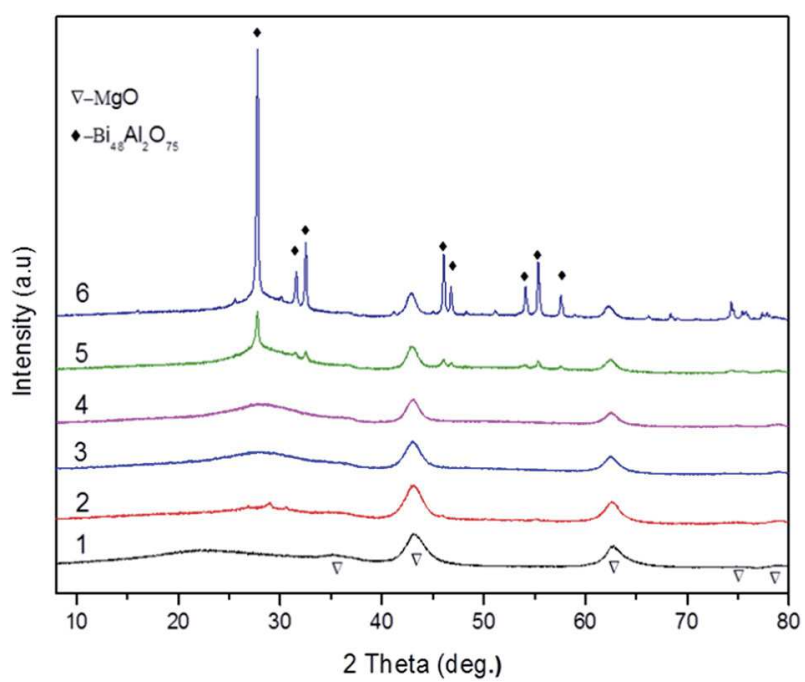

Fig. $10 \mathrm{XRD}$ patterns of $\mathrm{Mg}_{3} \mathrm{Al}_{1}{ }_{-x} \mathrm{Bi}_{x(\mathrm{co}-\mathrm{pr})}$ samples annealed at $650^{\circ} \mathrm{C}: x=0$ (1), $x=0.1$ (2), $x=0.2(3), x=0.3(4), x=0.4$ (5) and $x=0.5(6)$

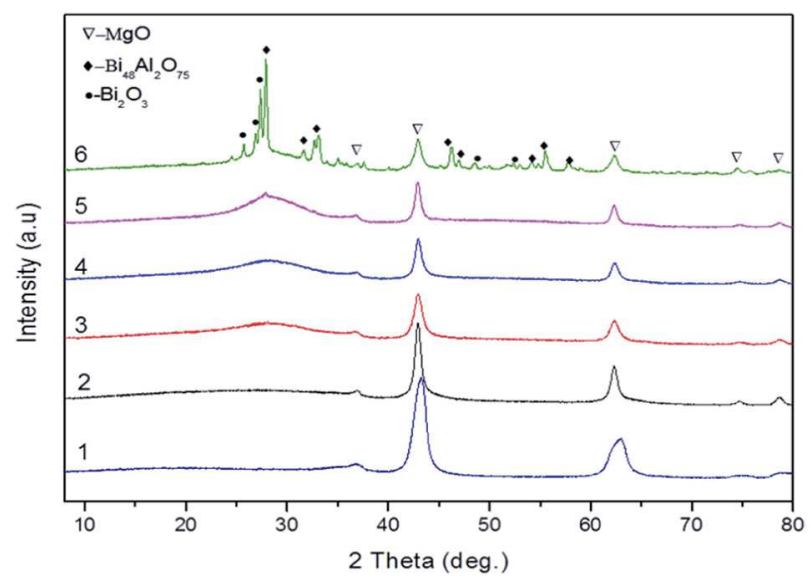

Fig. $11 \mathrm{XRD}$ patterns of $\mathrm{Mg}_{3} \mathrm{Al}_{1-x} \mathrm{Bi}_{x(\mathrm{sg})}$ samples annealed at $650{ }^{\circ} \mathrm{C}: x=0(1), x=0.1(2), x=0.2(3), x=0.3(4), x=0.4(5)$ and $x=0.5(6)$

were successfully reformed back to the layered structure, since in both cases single phase $\mathrm{Mg} / \mathrm{Al}-\mathrm{CO}_{3} \mathrm{LDH}$ (JCPDS 22-0700) were obtained. Intense and narrow diffraction peaks at $11^{\circ}$ and $22^{\circ}$, ascribed to (003) and (006) planes, respectively, are clearly seen in both reconstructed $\mathrm{Mg} / \mathrm{Al}$ LDH samples. As usually, asymmetric reflections (0kl) having different shape were obtained above $30^{\circ}$ of $2 \theta$. Reflections (110) and (113) noticed in $60^{\circ}-62^{\circ} 2 \theta$ confirm that reformation was complete. However, the reformation of $\mathrm{Mg} / \mathrm{Al} / \mathrm{Bi} \mathrm{LDH}$ synthesised by co-precipitation and sol-gel methods gave slightly different results (see also Figs. 12, 13). In the case of co-precipitation method, two additional crystalline phases $\left(\mathrm{Bi}_{24} \mathrm{Al}_{2} \mathrm{O}_{39}\right.$ and $\left.\mathrm{Bi}_{2} \mathrm{O}_{3}\right)$ can form during the reconstruction process. Bismuth oxide can be observed only at higher substitutional level of bismuth (40-50\%). 
When bismuth part is lower (10-30\%) only LDH and $\mathrm{Bi}_{24} \mathrm{Al}_{2} \mathrm{O}_{39}$ (JCPDS 42-0184) could be determined from the XRD patterns. Thus, the obtained results show that full reformation to $\mathrm{Mg} / \mathrm{Al} / \mathrm{Bi} \mathrm{LDH}$ is not possible because part of bismuth and aluminium crystallises into the bismuth aluminate $\mathrm{Bi}_{24} \mathrm{Al}_{2} \mathrm{O}_{39}$. Interestingly, during the reconstruction of sol-gel-derived $\mathrm{MMO}$ the formation of $\mathrm{Bi}_{24} \mathrm{Al}_{2} \mathrm{O}_{39}$ phase has not been observed. When the amount of bismuth was about $10-30 \%$ only $\mathrm{LDH}$ and negligible amount of $\mathrm{Bi}_{2} \mathrm{O}_{3}$ have formed during the reformation process. With increasing amount of bismuth up to $40-50 \%$, the predominant crystalline phase was $\mathrm{Bi}_{2} \mathrm{O}_{3} \mathrm{CO}_{3}$. Thus, the term "reconstruction" we use to describe the reconstruction of sol-gel-derived MMO is not correct. In fact, this is a novel sol-gel synthesis approach developed for the fabrication of bismuth-containing LDH.

The diffraction peaks (003), (006) and (110) presented in the XRD patterns allow to calculate the $a$ and $c$ cell parameters of as-prepared and reconstructed LDH. The

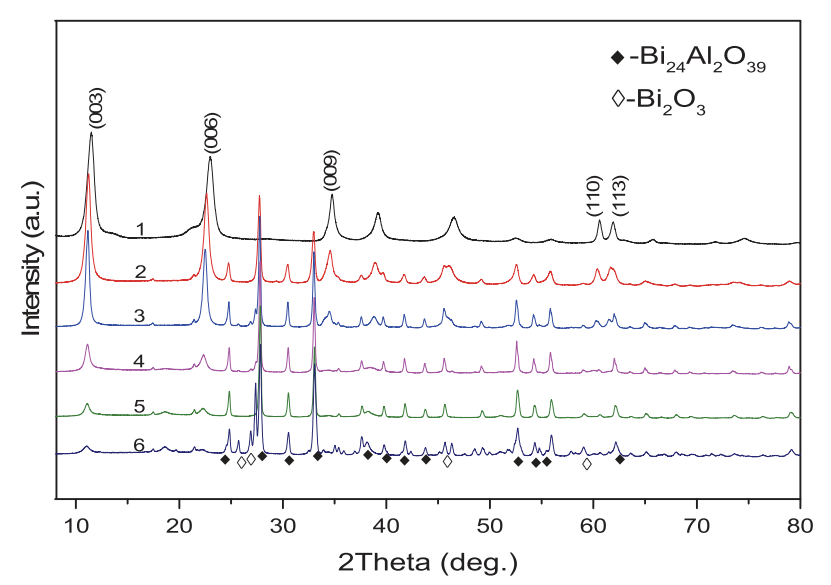

Fig. 12 XRD patterns of the products obtained after reconstruction of MMO powders prepared by co-precipitation method. The nominal $\mathrm{Mg}_{3} \mathrm{Al}_{1-x} \mathrm{Bi}_{x}$ composition: $x=0$ (1), $x=0.1(2), x=0.2(3), x=0.3$ (4), $x=0.4$ (5) and $x=0.5$ (6) parameter $a$ shows average distance between cations in cation hydroxide layer. Another parameter $c$ show the distance between layers, so called basal space. Both $a$ and $c$ parameters were calculated from XRD patterns using equations $c=3 / 2[\mathrm{~d}(003)+2 \mathrm{~d}(006)]$ and $a=2 \mathrm{~d}(110)$ [1]. The predicted $a$ parameter has been calculated according to Richardson's suggested formula $a=2 \sin (\alpha / 2)\left(r\left(M^{2+}\right)+r\right.$ $\left(O H^{-}\right)-2 \sin (\alpha / 2)\left(r\left(M^{2+}\right)-r\left(M^{3+}\right)\right) x$ which shows how theoretically parameter will be changed [25]. The results given in Table 1 show that cell parameter of $\mathrm{Mg} / \mathrm{Al} \mathrm{LDH}$ prepared using co-precipitation and sol-gel methods and then reconstructed are almost the same and are in a good agreement with literature data [1]. These results also prove that annealing and reconstructing conditions were selected correctly and the reconstruction process to layered structure was successful. In the case of $\mathrm{Mg} / \mathrm{Al} / \mathrm{Bi}$ samples fabricated by both synthesis methods the both $a$ and $c$ parameters increased with increasing substitutional level of bismuth. This is not surprising, since the ionic radii of $\mathrm{Bi}^{3+}(1.03 \AA)$

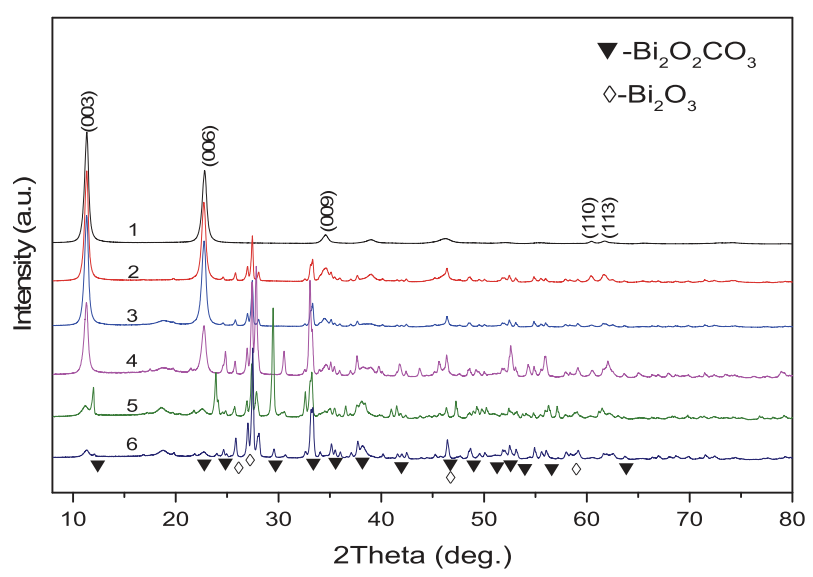

Fig. 13 XRD patterns of the products obtained after reconstruction of MMO powders prepared by sol-gel method. The nominal $\mathrm{Mg}_{3} \mathrm{Al}_{1-x}$ $\mathrm{Bi}_{x}$ composition: $x=0(1), x=0.1(2), x=0.2(3), x=0.3(4), x=0.4$ (5) and $x=0.5$ (6)
Table 1 Crystallographic data of formed and reconstructed LDH

\begin{tabular}{lllllll}
\hline Compound & $\mathrm{d}(003), \AA$ & $\mathrm{d}(006), \AA$ & $\mathrm{d}(110), \AA$ & $c, \AA(\mathrm{XRD})$ & $a, \AA$ (XRD) & $a, \AA$ (Predicted) \\
\hline $\mathrm{Mg}_{3} \mathrm{Al}_{1(\mathrm{co}-\mathrm{pr})}$ & 7.7210 & 3.8703 & 1.5276 & 23.1924 & 3.0510 & 3.0635 \\
$\mathrm{Mg}_{3} \mathrm{Al}_{1(\mathrm{co}-\mathrm{pr} / \mathrm{w} 80)}$ & 7.7130 & 3.8735 & 1.5278 & 23.1901 & 3.0555 & 3.0635 \\
$\mathrm{Mg}_{3} \mathrm{Al}_{1(\mathrm{sg} / \mathrm{w} 80)}$ & 7.7022 & 3.9450 & 1.5326 & 23.3883 & 3.0594 & 3.0635 \\
$\mathrm{Mg}_{3} \mathrm{Al}_{0.9} \mathrm{Bi}_{0.1(\mathrm{co}-\mathrm{pr})}$ & 7.8680 & 3.9178 & 1.5321 & 23.5554 & 3.0650 & 3.0821 \\
$\mathrm{Mg}_{3} \mathrm{Al}_{0.8} \mathrm{Bi}_{0.2(\mathrm{co}-\mathrm{pr})}$ & 7.9460 & 3.9699 & 1.5371 & 23.8287 & 3.0742 & 3.1007 \\
$\mathrm{Mg}_{3} \mathrm{Al}_{0.9} \mathrm{Bi}_{0.1(\mathrm{co}-\mathrm{pr} /}$ & 7.7870 & 3.9088 & 1.5300 & 23.4069 & 3.0600 & 3.0821 \\
$\mathrm{w80)}$ & & & & & \\
$\mathrm{Mg}_{3} \mathrm{Al}_{0.8} \mathrm{Bi}_{0.2(\mathrm{co}-\mathrm{pr} /}$ & 7.9730 & 3.9870 & 1.5293 & 23.9205 & 3.0586 & 3.1007 \\
$\mathrm{w80}$ & & & & & & \\
$\mathrm{Mg}_{3} \mathrm{Al}_{0.9} \mathrm{Bi}_{0.1(\mathrm{sg} / \mathrm{w} 80)}$ & 7.8500 & 3.9144 & 1.5320 & 23.5212 & 3.0662 & 3.0821 \\
$\mathrm{Mg}_{3} \mathrm{Al}_{0.8} \mathrm{Bi}_{0.2(\mathrm{sg} / \mathrm{w} 80)}$ & 7.8295 & 3.9155 & 1.5318 & 23.4908 & 3.0636 & 3.1007 \\
\hline
\end{tabular}


Fig. 14 SEM micrographs of $\mathrm{Mg}_{3} \mathrm{Al}_{0.9} \mathrm{Bi}_{0.1}$ synthesised by co-precipitation method: 1as prepared $\mathrm{LDH}, \mathbf{2}$ annealed at $650{ }^{\circ} \mathrm{C}$ and 3 reconstructed LDH in water at $80^{\circ} \mathrm{C}$

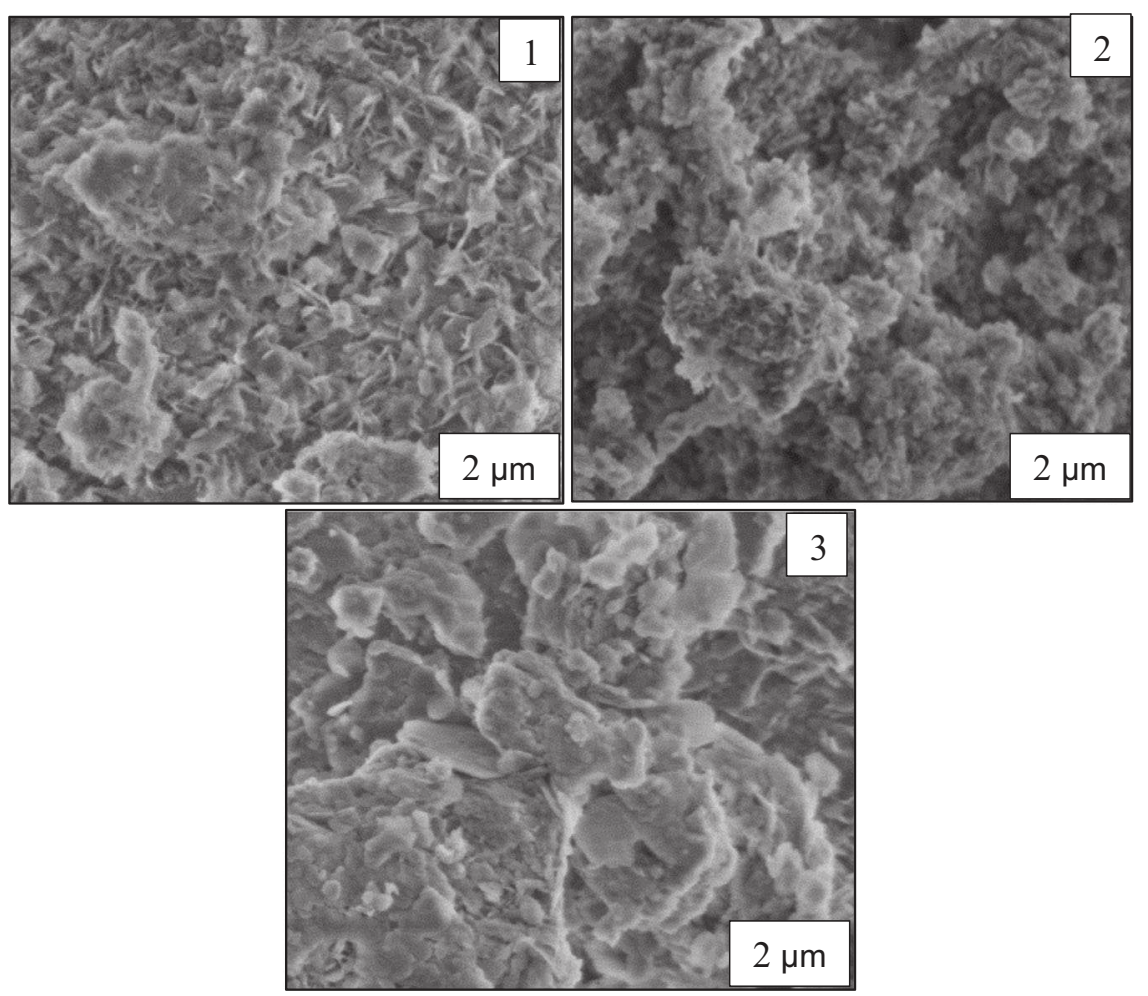

is much bigger than $\mathrm{Al}^{3+}(0.535 \AA)$. Therefore, partial substitution of aluminium by bismuth occurred. The values of predicted and calculated $a$ parameters are also close to each other.

The surface morphology of the prepared samples was investigated by SEM. The SEM micrographs of as prepared by co-precipitation method bismuth-containing LDH, annealed at $650{ }^{\circ} \mathrm{C}$ specimens and reconstructed LDH are shown in Fig. 14. The characteristic microstructure of synthesised LDH could be determined from the SEM micrograph. The formation of plate-like particles $0.5-2 \mu \mathrm{m}$ in size with hexagonal shape is evident. After calcination of $\mathrm{Mg} / \mathrm{Al} / \mathrm{Bi} \mathrm{LDH}$ at $650{ }^{\circ} \mathrm{C}$ collapse of the $\mathrm{LDH}$ structure and appearance of porous mixed metal oxide structure was noticed. A layered double structure recovered after reconstruction procedure showed the formation of plate-like particles with more pronounced agglomeration (see Fig. 14). The particle size of LDH obtained after reconstruction remained almost the same. The surface morphology of sol-gel-derived $\mathrm{Mg}-\mathrm{Al}-\mathrm{Bi}-\mathrm{O}$ precursor (see Fig. 15) differs very much from typical microstructure of LDH. The representative SEM micrograph confirmed the formation of monolithic gel, in which individual particles were hardly distinguishable. On the other hand, the morphological features of the heat-treated sol-gel precursor at $650{ }^{\circ} \mathrm{C}$ were almost identical to the MMO synthesised by coprecipitation method. The reconstruction method regenerated the metal hydroxide sheets and the plate-like geometry of the primary particles. Sol-gel-derived $\mathrm{Mg} / \mathrm{Al} /$ Bi LDH consist of the larger hexagonally shaped particles varying in size from approximately $200-500 \mathrm{~nm}$. The good connectivity between the grains was observed. These nanograins showed tendency to form larger agglomerates. Nanocrystalline nature of powders with the narrow size distribution of crystallites was observed in the LDH samples.

\section{Conclusions}

The bismuth containing $\mathrm{LDH} \mathrm{Mg}_{3} \mathrm{Al}_{1-}{ }_{-} \mathrm{Bi}_{x}(\mathrm{x} \leqslant 0.2)$ were prepared by low saturation co-precipitation method from carbonate-containing solutions. For the first time to the best of our knowledge the $\mathrm{Mg}_{3} \mathrm{Al}_{1-x} \mathrm{Bi}_{x} \mathrm{LDH}$ were synthesised by an aqueous sol-gel processing. It was demonstrated that sol-gel method is not suitable for the direct synthesis of LDH. In both synthesis methods, the calcination temperature was experimentally chosen to be $650{ }^{\circ} \mathrm{C}$. It was determined, that in both synthesis the spinel $\mathrm{MgAl}_{2} \mathrm{O}_{4}$ phase was forming at temperature higher than $700^{\circ} \mathrm{C}$. Materials prepared by co-precipitation method showed the collapse of the $\mathrm{LDH}$ structure at $650^{\circ} \mathrm{C}$ and appearance of porous mixed-metal oxide structure. According to the XRD patterns, the single phase $\mathrm{Mg}(\mathrm{Al}) \mathrm{O}$ or $\mathrm{Mg}(\mathrm{AlBi}) \mathrm{O}$ 
Fig. 15 SEM micrographs of $\mathrm{Mg}_{3} \mathrm{Al}_{0.9} \mathrm{Bi}_{0.1}$ synthesised by so1-gel method: 1 sol-gel precursor, 2 annealed at $650{ }^{\circ} \mathrm{C}$, 3 reconstructed (synthesised) $\mathrm{LDH}$ in water at $80^{\circ} \mathrm{C}$

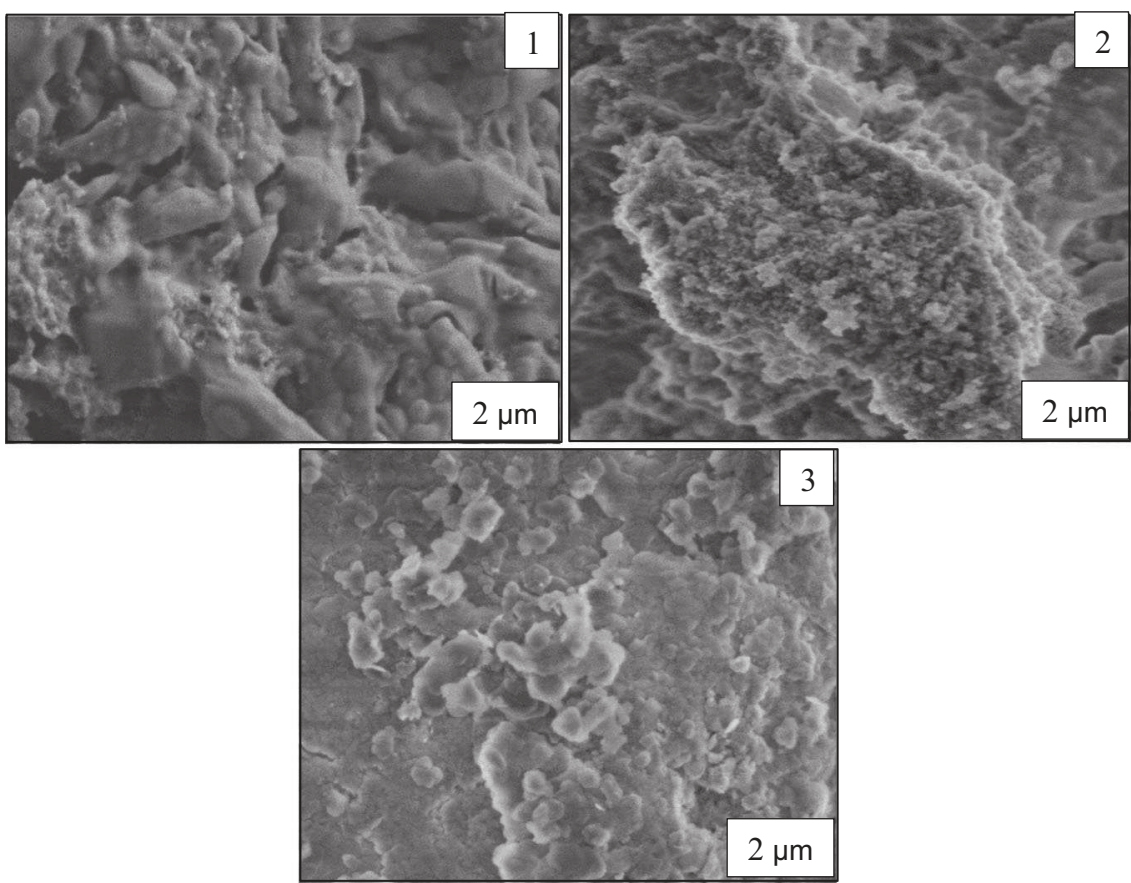

mixed-metal oxides have been formed during annealing of sol-gel precursors at this temperature and no other insoluble phases were obtained. In comparison with co-precipitation method the MMO from sol-gel precursors have been formed with higher crystallinity despite the LDH did not form during the sol-gel processing. Reconstruction of annealed samples at $80^{\circ} \mathrm{C}$ in water showed the typical microstructure for the LDH materials with formation of flake-shaped particles. The XRD results showed that cell parameters of $\mathrm{Mg}$ / Al LDH prepared using co-precipitation and sol-gel methods and then reconstructed are in a good agreement. In the case of $\mathrm{Mg} / \mathrm{Al} / \mathrm{Bi}$ the both $a$ and $c$ parameters increased with increasing substitutional level of bismuth. Thus, the partial substitution of aluminium by bismuth occurred, since the ionic radius of $\mathrm{Bi}^{3+}(1.03 \AA)$ is bigger than $\mathrm{Al}^{3+}(0.535 \AA)$. SEM observation also proved that only co-precipitation method effective for the direct synthesis of LDH. On the other hand, the reconstruction method regenerated the metal hydroxide sheets in the sol-gel-derived MMO. Sol-gelderived $\mathrm{Mg} / \mathrm{Al} / \mathrm{Bi} \mathrm{LDH}$ consisted of the larger hexagonally shaped particles varying in size from approximately 200-500 nm. The good connectivity between the grains was also observed.

Acknowledgements The work has been done in frame of the project TUMOCS. This project has received funding from the European Union's Horizon 2020 research and innovation programme under the Marie Sklodowska-Curie grant agreement No. 645660.

\section{References}

1. Evans DE, Slade RCT (2005) Structural aspects of layered double hydroxides. In: Duan X, Evans DG (eds) Structure \& bonding. Springer-Verlag, Berlin, p 1-87

2. Twu J, Dutta PK (1989) Structure and reactivity of oxovanadate anions in layered lithium aluminate materials. J Phys Chem 93:7863-7868

3. Khan AI, O'Hare D (2002) Intercalation chemistry of layered double hydroxides: recent developments and applications. J Mater Chem 12:3191-3198

4. Bookin AS, Drits VA (1993) Polytype diversity of the hydrotalcite-like minerals I. Possible polytypes and their diffraction features. Clays Clay Miner 41:551

5. Bookin AS, Cherkashin VI, Drits VA (1993) Polytype diversity of the hydrotalcite-like minerals II. Determination of the polytypes of experimentally studied varieties. Clays Clay Miner 41:558

6. Ennadi A, Legrouri A, De Roy A, Besse JP (2000) X-ray diffraction pattern simulation for thermally treated [ $\mathrm{Zn}{ }^{\prime} \mathrm{Al} \mathrm{Cl}^{\prime} \mathrm{Cl}$ layered double hydroxide. J Solid State Chem 152:568-572

7. Salak AN, Lisenkov AD, Zheludkevich ML, Ferreira MGS (2014) Carbonate-free $\mathrm{Zn}-\mathrm{Al}$ (1:1) layered double hydroxide film directly grown on zinc-aluminum alloy coating. ECS Electrochem Lett 3: C9-C11

8. Radha AV, Vishnu Kamath P, Shivakumara C (2007) Conservation of order, disorder, and "crystallinity" during anion-exchange reactions among layered double hydroxides (LDHs) of $\mathrm{Zn}$ with Al. J Phys Chem B 111:3411-3418

9. Serdechnova M, Salak AN, Barbosa FS, Vieira DEL, Tedim J, Zheludkevich ML, Ferreira MGS (2016) Interlayer intercalation and arrangement of 2-mercaptobenzothiazolate and 1,2,3-benzotriazolate anions in layered double hydroxides: in situ X-ray diffraction study. J Solid State Chem 233:158-165

10. Meyn M, Beneke K, Lagaly G (1990) Anion-exchange reactions of layered double hydroxides. Inorg Chem 29:5201-5207

11 Millange F, Walton RI, Lei L, O'Hare D (2000) Efficient separation of terephthalate and phthalate anions by selective ion- 
exchange intercalation in the layered double hydroxide $\mathrm{Ca}_{2} \mathrm{Al}$ $(\mathrm{OH})_{6} \cdot \mathrm{NO}_{3} \cdot 2 \mathrm{H}_{2} \mathrm{O}$. Chem Mater 12:1990-1994

12. Vichi FM, Alves OL (1997) Preparation of Cd/Al layered double hydroxides and theirintercalation reactions with phosphonic acids. J Mater Chem 7:1631-1634

13. Srankó D, Pallagi A, Kuzmann E, Canton SE, Walczak M, Sápi A, Kukovecz A, Kónya Z, Sipos P, Pálinkó I (2010) Synthesis and properties of novel $\mathrm{Ba}$ (II)Fe(III) layered double hydroxides. Appl Clay Sci 48:214-217

14. Silva CG, Bouizi Y, Fornés V, García H (2009) Layered double hydroxides as highly efficient photocatalysts for visible light oxygen generation from water. J Am Chem Soc 131:13833-13839

15. Wang Y, Gao H (2006) Compositional and structural control on anion sorption capability of layered double hydroxides (LDHs). J Colloid Interface Sci 301:19-26

16. Jaiswal A, Chattopadhyaya MC (2013) Synthesis and characterization of novel $\mathrm{Co} / \mathrm{Bi}$-layered double hydroxides and their adsorption performance for lead in aqueous solution. Arab J Chem. https://doi.org/10.1016/j.arabjc.2013.09.010

17. Salak AN, Ferreira VM (2007) Microwave dielectric properties of Bi-substituted $\mathrm{La}(\mathrm{Mg} 1 / 2 \mathrm{Ti1} / 2) \mathrm{O}$. J Eur Ceram Soc 27: 2887-2891

18. Salak AN, Ferreira VM, Ribeiro JL, Vieira LG, Pullar RC, Alford NM (2008) Bismuth-induced dielectric relaxation in the $(1-\mathrm{x}) \mathrm{La}$ $(\mathrm{Mg} 1 / 2 \mathrm{Ti} / 2) \mathrm{O} 3-\mathrm{xBi}(\mathrm{Mg} 1 / 2 \mathrm{Ti} / 2) \mathrm{O} 3(1-\mathrm{x}) \mathrm{La}(\mathrm{Mg} 1 / 2 \mathrm{Ti} / 2)$ $\mathrm{O} 3-\mathrm{xBi}(\mathrm{Mg} 1 / 2 \mathrm{Ti} / 2) \mathrm{O} 3$ perovskite system. J Appl Phys 104 (1):014105
19. Khalyavin DD, Salak AN, Olekhnovich NM, Pushkarev AV, Radyush YV, Manuel P, Raevski IP, Zheludkevich ML, Ferreira MGS (2014) Polar and antipolar polymorphs of metastable perovskite $\mathrm{BiFe}_{0.5} \mathrm{Sc}_{0.5} \mathrm{O}_{3}$. Phys Rev B 89:174414

20. Khalyavin DD, Salak AN, Lopes AB, Olekhnovich NM, Pushkarev AV, Radyush YV, Fertman EL, Desnenko VA, Fedorchenko AV, Manuel P, Feher A, Vieira JM, Ferreira MGS (2015) Magnetic structure of an incommensurate phase of La-doped $\mathrm{BiFe}_{0.5} \mathrm{Sc}_{0.5} \mathrm{O}_{3}$ : role of antisymmetric exchange interactions. Phys Rev B 92:224428

21. Fu WT, de Gelder R, de Graaff RAG (1997) Crystal structure of the ordered perovskite: BaBi0.5Sb0.5O3. Mater Res Bull 32:651

22. Blanchard PER, Huang Z, Kennedy BJ, Liu S, Miiller W, Reynolds E, Zhou Q, Avdeev M, Zhang Z, Aitken JB, Cowie BCC, Jang LY, Tan TT, Li S, Ling CD (2014) Key role of bismuth in the magnetoelastic transitions of $\mathrm{Ba}_{3} \mathrm{BiIr}_{2} \mathrm{O}_{9}$ and $\mathrm{Ba}_{3} \mathrm{BiRu}_{2} \mathrm{O}_{9}$ as revealed by chemical doping. Inorg Chem 53:952

23 Trave A, Selloni A, Goursot A, Tichit D, Weber J (2002) First principles study of the structure and chemistry of Mg-based hydrotalcite-like anionic clays. J Phys Chem B 106:12291

24. Perez-Ramirez J, Abello S, van der Pers NM (2007) Influence of the divalent cation on the thermal activation and reconstruction of hydrotalcite-like compounds. J Phys Chem C 111:3642-3650

25. Richardson IG (2013) Zn- and Co-based layered double hydroxides: prediction of the a parameter from the fraction of trivalent cations and vice versa. Acta Crystallogr B Struct Sci Cryst Eng Mater B69:414-417 